\title{
EKSEKUSI HUKUMAN MATI DI INDONESIA (TINJAUAN HUKUM PIDANA ISLAM)
}

\author{
Nurwahidah \\ Fakultas Syariah dan Ekonomi Islam, Jl. A. Yani Km, 4.5 Banjarmasin \\ e-mail : nurwahidah_97@yahoo.co.id
}

\begin{abstract}
The death penalty is still carried out in many countries, including Indonesia. Considering the death penalty concerning human lives, then multiply the pros and cons of going on in the community, but the Indonesian government together with some elements of society who support the death penalty remains on the establishment, that the death penalty should still be implemented to protect life. This paper seeks to inform some of the death penalty that has been implemented for a variety of specific criminal acts. This paper seeks to criticize, the extent of execution cases it can be justified according to Islamic criminal law. The results of this paper show the majority of crimes are indeed subject to the death penalty, there are still containing the controversy, but some are actually able to be released from the death penalty because the victim's family in a murder case has been forgiven.
\end{abstract}

Abstrak: Hukuman mati masih dilaksanakan di banyak negara, termasuk Indonesia. Mengingat hukuman mati menyangkut nyawa manusia, maka banyaklah terjadi pro dan kontra di tengah masyarakat, namun pemerintah Indonesia bersama sejumlah elemen masyarakat yang mendukung hukuman mati tetap pada pendirian, bahwa hukuman mati tetap harus dilaksanakan untuk melindungi kehidupan. Tulisan ini berusaha menginformasikan beberapa hukuman mati yang sudah dilaksanakan untuk berbagai tindak pidana tertentu. Tulisan ini berusaha mengkritisi, sejauhmana kasus-kasus eksekusi mati itu dapat dibenarkan menurut hukum pidana Islam. Hasil tulisan ini menunjukkan sebagian tindak pidana tersebut memang dapat dikenakan hukuman mati, ada yang masih mengandung kontroversi, namun ada pula yang sebenarnya dapat dilepaskan dari hukuman mati karena pihak keluarga korban dalam kasus pembunuhan sudah memaafkan.

Keywords: Execution of the death penalty, criminal law of Islam

\section{Pendahuluan}

Hukuman mati adalah salah satu hukuman tertua di dunia. Dalam sejarah, dikenal beberapa cara pelaksanaan hukuman mati, seperti hukuman pancung hukuman dengan cara potong kepala sebagaimana berlaku di Arab Saudi. Sengatan listrik: hukuman dengan cara duduk di kursi yang kemudian dialiri listrik bertegangan tinggi sebagaimana diberlakukan di Amerika. Hukuman gantung: hukuman dengan cara digantung di tiang gantungan sebagaimana diberlakukan di Irak, Mesir dan Malaysia. Suntik mati, hukuman dengan cara disuntik obat yang dapat membunuh pernah diberlakukan di Amerika. Hukuman tembak, hukuman dengan cara menembak jantung seseorang, sebagaimana diberlakukan di Indonesia. Rajam: hukuman dengan cara dilempari batu hingga mati untuk pelaku perzinaan sebagaimana berlaku di Arab Saudi. Dahulunya, di masa Revousi Perancis juga dilaksanakan hukuman mati dengan menggunakan alat penggal kepala bernama guilotine.
Pemerintah Indonesia sudah beberapa kali melaksanakan eksekusi hukuman mati terhadap pelaku tindak pidana tertentu. Pada umumnya pelaku tindak pidana yang dikenakan hukuman mati tersebut adalah berkaitan dengan pembunuhan, terorisme dan pemberontakan (makar).

Setiap kali pemerintah, dalam hal ini Kejaksaan melaksanakan hukuman mati, selalu saja timbul kontroversi. Dalam arti ada yang setuju terhadap hukuman mati tersebut dan ada yang tidak setuju. Ada pula kalangan yang mengusulkan agar hukuman mati juga diberlakukan terhadap pelaku tindak pidana korupsi (koruptor), tetapi kelihatannya pemerintah tidak mau, karena takut dianggap melanggar hak asasi manusia (HAM).

Tampaknya pemerintah belum begitu keras dalam hal menjatuhkan hukuman mati. Bahkan untuk kasus-kasus pembunuhan, meskipen sering sekali terjadi, namun hukuman mati masih relatif jarang dikenakan kepada para pelakunya. Maksimal hanya hukuman penjara selama puluhan tahun, bahkan ada yang relatif ringan, 
akibatnya pembunuhan masih sering terjadi di negeri ini.

Masyarakat juga sering mengusulkan agar pelaku tindak pidana penyalahgunaan narkotika juga dihukum mati, khususnya kelas kakap, sebagaimana sering dilakukan oleh sejumlah negara seperti Malaysia dan Singapura yang menghukum berat pelakunya (mati). Namun pemerintah kelihatannya juga mash ragu, sehingga banyak dari mereka yang hanya dihukum ringan. Akibatnya kejahatan narkotika di Indonesia tetap tinggi.

Berkenaan dengan masalah ini, tulisan ini mencoba mengkritisi beberapa hukuman mati yang sudah dilaksanakan, juga menyoroti sejumlah tuntutan hukuman mati, namun pemerintah masih enggan melakukan, seperti kejahatan korupsi dan narkotika.

\section{Beberapa Contoh Hukuman Mati Yang Sudah Dieksekusi}

Jika kita aktif mengikuti pemberitaan media massa dalam beberapa puluh tahun terakhir, maka kita akan mengetahui beberapa pelaku tindak pidana yang dijatuhi hukuman mati dan sudah pula dieksekusi. Di sini dikemukakan beberapa contoh, serta kasus yang menyebabkan pelaku terkena hukuman tersebut.

\section{Kusni Kasdut}

Kusni Kasdut sebelum terjerumus ke dunia hitam adalah tentara pejuang yang ikut melawan penjajah Belanda pada masa revolusi 1945. Setelah itu dia berusaha masuk TNI namun beberapa kali ditolak.

Karena terdesak masalah ekonomi, Kusni Kasut terjun ke dunia hitam dengan menjadi perampok. Selain untuk keperluan sendiri, ia membagikan harta rampokannya kepada orangorang miskin, hingga dia dijuluki 'Robin Hood Indonesia'. Pada tahun 1960-an, dengan sepucuk pistol ia menembak seorang keturunan Arab kaya bernama Ali Bajhened, namun belum berhasil ditangkap. Kemudian namanya makin berkibar sebagai pencuri benda seni saat dia merampok Museum Nasional yang akrab disebut Museum Gajah pada 31 Mei 1961. Kusni menyamar dengan mengenakan seragam polisi, masuk ke museum, menyandera pengunjung dan menembak mati seorang petugas museum. Sebanyak 11 permata koleksi museum yang bernilai tinggi dibawa lari.

Kusni kemudian ditangkap saat menjual permatanya di Semarang. Kusni kemudian dijatuhi hukuman mati atas kejahatan yang dilakukannya. Di penjara, Kusni kemudian bertobat dan dia dibaptis menjadi pemeluk Katolik dengan nama Ignatius Waluyo. Sebelum dihukum mati, Kusni sempat membuat lukisan Katedral yang masih tersimpan di Katedral Jakarta. Untuk menghindari hukuman mati, ia mengajukan grasi kepada Presiden Soeharto, namun ditolak. Kabar grasinya yang ditolak presiden diterimanya saat dia mendekam di LP Kalisosok pada Februari 1980. Kusni kemudian dieksekusi pada 16 Februari 1980 di dekat kota Gresik, Jawa Timur.

\section{Salman Hafiz dan Imran bin Muhammad Zein}

Keduanya dihukum mati karena terkait dengan perkara makar terhadap negara, yang sekarang disebut dengan terorisme. Gerakan mereka dulu disebut dengan Komando Jihad. Salman Hafiz pernah menyerang pos polisi di Cicendo Jawa Barat, melukai dan membunuh sejumlah personalnya, serta merampas senjata mereka pada tahun 1983.

Sedangkan Imran bersama kelompoknya melakukan pembajakan pesawat Garuda di Bandara Don Muang Thailand. Sejumlah penyandra berhasil dilumpuhkan oleh pasukan khusus antiteror ABRI saat itu. Sedangkan Imran yang dianggap sebagai otak pembajakan ini tertangkap kemudian. Mereka kemudian divonis dan dihukum mati, Imran dieksekusi pada tahun 1983 dan Salman tahun 1985.

\section{Oesin Baftari}

Pedagang kambing sekaligus tukang jagal kambing ini ditembak regu tembak pada 14 September 1978 pada waktu subuh. Dia dibunuh di tepi pantai di daerah Kenjeran, Surabaya. Warga Desa Jagalan, Mojokerto, Jawa Timur ini ditembak mati karena membunuh 6 rekan bisnisnya pada tahun 1964. Pembunuhan pertama ia lakukan di rumahnya di Desa Jagalan. Lima orang lainnya ia bunuh di sebuah rumah yang disewanya di Desa Seduri, di pinggir jalan raya antara Mojokerto-Surabaya.

Setelah pembunuhan pertama rupanya ia sudah merencanakan pembunuhan-pembunuhan selanjutnya. Untuk itu ia menyewa rumah milik Abdul Wahid di Desa Seduri. Kejahatan keji tersebut terbongkar saat dia menghabisi korban keenamnya. Sebab, korbannya itu sempat berteriak minta tolong sebelum menghembuskan 
nafas terakhir. Teriakan ini didengar tetangganya dan membuat aksinya terkuak.

\section{Ayub Bulubili}

Ayub Bulubili dieksekusi akhir April 2008.. Eksekusi mati diterima oleh Ayub karena perbuatannya membantai Heri Witarko sekeluarga di Sampit Kalimantan Tengah tahun 1999. Tindakan agresif almarhum Ayub dipicu karena masalah ekonomi. Ia mau meminjam uang kepada tetangganya yang dianggap memiliki uang lebih. Merasa tidak diberi utangan, ia nekad menghabisi Heri Witarko bersama anak istrinya.

Sepuluh tahun sesudah kejadian perkara, barulah eksekusi dilaksanakan. Hukuman lama tertunda karena berbagai upaya hukum yang dlakukan oleh pembela terpidana. Eksekusi ini mengundang protes keras dari Amnesti Internasional (AI). AI beralasan, hukuman mati di negara mana pun bukan solusi, sebab tidak ada bukti valid hukuman mati mampu mencegah kejahatan dibanding bentuk hukuman lain.

\section{Fabianus Tibo cs}

Fabianus Tibo bersama dua orang rekannya yaitu Dominggus da Silva dan Marinus Riwu adalah terpidana rusuh Poso tahun 1999-2000. Kerusuhan bernuansa SARA ini banyak mengorbankan umat Islam, sehingga terjadi eksodus besar-besaran dari sejumlah kawasan Indonesia Timur ke kawasan lain yang lebih aman yaitu ke Sulawesi Tengah. Mereka dihukum mati karena terkait kerusuhan Poso. Mereka ditangkap pada Juli dan Agustus tahun 2000, lalu dijatuhi vonis mati pada April 2001 di Pengadilan Negeri Palu.

Tibo cs dan pengacaranya tidak terima lalu mengajukan banding ke Pengadilan Tinggi. Namun vonis mati ditegaskan atau dikuatkan kembali oleh Pengadilan Tinggi Sulawesi Tenggara pada 17 Mei 2001. Pengadilan memutuskan bahwa mereka bersalah atas tuduhan pembunuhan, penganiayaan, dan perusakan di tiga desa di Poso, khususnya di Desa Sintuwu Lemba, Kayamaya, dan Maengko Baru. ${ }^{1}$

Ketiganya dieksekusi pada 22 September 2006 dini hari di Palu. Menyikapi eksekusi mati ini Amnesti International juga melakukan protes keras dan mengingatkan hukuman mati yang

Zainuddin Daulay (Editor), Konflik Sosial Bernuansa Agama di Indonesia, Jakarta; Departemen Agama, 2003), hlm. 86-90. sudah, sedang dan akan dilakukan di Indonesia bertentangan dengan International Covenant on Cipil and Political Rights (ICCPR), padahal Indonesia sudah meratifikasinya sejak 2006.

\section{Sumiasih cs}

Sumiasih cs divonis hukuman mati oleh Pengadilan Negeri Surabaya karena kejahatannya menghabisi Perwira Angkatan Laut Purwanto sekeluarga di Surabaya lebih 10 tahun silam. Setelah korban dibunuh, para pelaku lalu membakar dan membuang mayat-mayat korban di Songgoriti guna menghilangkan jejak. Menantu Sumiasih, Adi Saputro yang ikut dalam aksi pembantaian keluarga Purwanto tersebut divonis mati oleh Pengadilan Negeri Surabaya dan langsung dieksekusi mati segera setelah kasus heboh tersebut terbongkar. Kasus ini terjadi karena Sumiasih terlilit hutang sementara Purwanto terus mendesaknya. Hal ini membuat pelaku gelap mata dan kemudian menghabisi korban sekeluarga.

Awalnya yang ingin dibunuh cuma Letkol Purwanto, kepala keluarga, tetapi agar jejak kejahatan tersamar, dihabisilah yang lain yang kebetulan sedang naas.

Sumiasih walau juga divonis mati tetapi tidak langsung diekseskusi. Ia lebih dahulu menjalani hukuman badan di di LP Sokolilo. Sumiasih (60) dan anaknya Sugeng (40) baru dieksekusi Jumat tengah malam, pada tanggal 18 Juli 2008 di Surabaya.

Penting dikomentari, lamanya rentang waktu antara kejadian perkara, vonis dengan eksekusi. Sumiasih dan keluarganya melakukan pembunuhan berencana atas lima orang keluarga Letkol Marinir Poerwanto Agustus 1988 silam, dan baru dieksekusi Juli 2008. Berarti sekitar 20 tahun Sumiasih dan Sugeng menjalani hukuman penjara. Dapat dikatakan, hukuman yang menimpa keduanya menjadi double/ganda, yaitu penjara dan mati. Waktu 20 tahun bukan masa singkat, sepertiga usia Sumiasih dan separoh usia Sugeng. Kalau akhirnya mati juga, lebih baik eksekusi secepatnya.

\section{Rio Alex Bullo alias Rio Martil}

Pelaku pembunuhan berantai kurun waktu antara tahun 1997-2001, Rio Alex Bullo (30) alias Rio Martil menghembuskan nyawa terakhir di depan regu tembak pada 7 Agustus 2008. Dia ditembak mati di tempat yang dirahasiakan di sebuah desa kecil di sekitar Purwokerto, Jawa 
Tengah. Sebelumnya, dia mendekam di LP Pasir Putih di Pulau Nusakambangan, Cilacap.

Rio Alex Bullo divonis mati Pengadilan Negeri (PN) Purwokerto karena melakukan pembunuhan sadis terhadap seorang pengacara terkenal sekaligus pemilik persewaan mobil di kota tersebut, Jeje Suraji (39), di Hotel Rosenda Baturaden, 21 Januari 2001. Selama 1997-2001, terpidana telah membunuh sedikitnya empat orang pemilik atau pengelola rental mobil. Pembunuhan itu merupakan cara terpidana untuk membawa lari mobil yang disewa dari para pemilik atau pengelola rental tersebut.

Setiap melancarkan aksinya, terpidana selalu menyiapkan dua buah martil untuk memukul kepala korbannya. Karena itu pula, terpidana diberi julukan Rio Si Martil Maut. Saat mendekam di LP Nusakambangan, terpidana juga membunuh teman satu penjaranya, Iwan Zulkarnaen.

\section{Ayodhya cs}

Ayodya Prasad Chaubey (india), Saelaw prasad (India), Samsong Sirilak (Thailand), ketiga warga asing ini melakukan kejahatan penyelundupan dan peredaran narkoba. Ketiganya djatuhi hukuman mati oleh Kejaksaan Negeri Medan Sumatra Utara tahun 2004. Sebelum diseksekusi Ayodhya memilih masuk Islam. Sebelumnya mereka menjalani tahanan penjara.

\section{Trio Bomber Bali Amrozi Cs}

Tiga terpidana mati Bom Bali, Amrozi, Ali Gufron alias Mukhlas, dan Imam Samudra ditembak mati pada 9 November 2008 waktu tengah malam. Ketiganya ditembak mati di Bukit Nirbaya, Pulau Nusa Kambangan. Amrozi dan Ali Ghufron dimakamkan di Tempat Pemakaman Umum Desa Tenggulun, Lamongan, Jawa Timur. Upacara pemakaman dipimpin ustadz Abu Bakar Ba'asyir.

Sebelum dimakamkan, kedua jenazah sempat disalatkan di Masjid Al Muttaqin dan Pondok Pesantren Al Muslim. Sedangkan Imam Samudra dimakamkan di Tempat Pemakaman Umum (TPU) Lopang Gede, Serang, Banten. Ketiganya terbukti secara sah dan meyakinkan sebagai otak pelaku peledakan di Legian, Kuta, Bali, 12 Oktober 2002.2

2 http:/ / forum.viva.co.id/aneh-dan-lucu/440907-5eksekusi-mati-paling-heboh-di-indonesia.html

\section{Kontroversi}

Kesembilan orang atau kelompok yang dijatuhi hukuman mati dan kemudian dieksekusi di atas mengandung kontroversi, dalam arti ada yang pro dan kontra.

Sejak lama hukuman mati jadi kontroversi, di dalam dan luar negeri. Di era 1980-an, aktivis Hak Asasi Manusia (HAM) memperjuangkan Hapus Hukuman Mati (HATI). Melalui berbagai tulisan, pembelaan di pengadilan dan aksi turun ke jalan mereka mengampanyekan penghapusan hukuman mati. HATI beralasan, hukuman mati terlalu final dan bertentangan dengan tujuan pemidanaan untuk memperbaiki manusia. HATI melihat, hukuman mati tidak terbukti berhasil mengurangi kejahatan, sebab kejahatan disebabkan banyak faktor, termasuk tekanan ekonomi.

Tetapi aksi HATI ditolak kelompok Pembela Hukuman Mati (PAHAMA), mereka terdiri dari pihak Kejaksaan Agung dan Majelis Ulama Indonesia (MUI) yang ingin hukuman mati tetap dipertahankan sebagai senjata pamungkas mengatasi kejahatan berat. Apa pun alasannya pembunuhan sangat dilarang, karena nyawa manusia tidak tergantikan. ${ }^{3}$

Seringnya hukuman mati akhir-akhir ini mengundang protes keras Amnesti Internasional (AI). AI beralasan, hukuman mati di negara mana pun bukan solusi, sebab tidak ada bukti valid hukuman mati mampu mencegah kejahatan dibanding bentuk hukuman lain. AI mencatat di Indonesia ada puluhan bahkan ratusan orang yang sudah dan akan terkena hukuman mati.. AI mengingatkan hukuman mati yang sudah, sedang dan akan dilakukan bertentangan dengan International Covenant on Cipil and Political Rights (ICCPR), padahal Indonesia meratifikasinya sejak 2006. ${ }^{4}$

Banyak kalangan juga menolak hukuman mati, karena kejahatan yang dilakukan oleh terpidana terkait dengan masalah atau beban ekonomi yang berat. Kejahatan memang sesuatu yang kompleks, tidak berdiri sendiri. Menurut sosiolog kriminal M Harvey Brenner, salah satu teori penyebab kejahatan adalah frustrasi-agresi. Karena putus asa seseorang bisa nekad mencuri, merampok, menganiaya, bahkan membunuh.

3 Todung Mulya Lubis (Editor), Langit Masih Mendung, Jakarta,Sinar Harapan, 1980, hlm. 58.

4 "Amnesti Internasional Protes Hukuman Mati", Tempo, edisi Juni 2008. 
Putus asa karena tekanan ekonomi tak jarang membuat orang gelap mata. ${ }^{5}$

Terbunuhnya Naek Gonggom Hutagalung pada tahun 2010, juga dilatari masalah ekonomi pelaku. Akibatnya artis muda dan cantik Lidya Pratiwi bersama ibu dan pamannya terkena hukuman berat, karena didakwa terlibat pembunuhan tersebut. Tentu masih banyak kasus serupa di mana masalah ekonomi sangat dominan memicu orang berbuat jahat, termasuk pembunuhan.

Namun bagi penegak hukum di Indonesia sudah dianggap sesuai dengan ketentuan hukum yang berlaku. Hal ini karena ada sejumlah peraturan perundang-undangan yang dapat dijadikan sebagai payung hukum pelaksanaan hukuman mati. Hingga tahun 2006 tercatat masih ada 11 peraturan perundang-undangan yang memiliki ancaman hukuman mati, seperti: KUHP, UU Subversif, UU Narkotika, UU Anti Korupsi, dan UU Pengadilan HAM. Daftar ini bisa bertambah panjang dengan adanya RUU Intelijen dan RUU Rahasia Negara.

Selain itu vonis atau hukuman mati masih mendapat dukungan yang luas dari pemerintah dan masyarakat Indonesia. Selama Orde Baru korban yang dieksekusi sebagian besar merupakan narapidana politik, sedangkan di masa reformasi kebanyakan yang dieksekusi mati adalah terpidana teorisme, pembunuhan dan narkotika. Pemungutan suara yang dilakukan media di Indonesia pada umumnya menunjukkan $75 \%$ dukungan untuk adanya vonis mati.

Kelompok pendukung hukuman mati beranggapan bahwa bukan hanya pembunuh saja yang punya hak untuk hidup dan tidak disiksa. Masyarakat luas juga punya hak untuk hidup dan tidak disiksa. Untuk menjaga hak hidup masyarakat, maka pelanggaran terhadap hak tersebut patut dihukum mati.

\section{Tinjauan Hukum Pidana Islam \\ Tinjauan Jarimah}

Sebelumn membahas kasus hukuman mati di atas dibahas dahulu perspekstif hukum Islam terhadap kejahatan (jarimab atau jinayab).

Istilah jarimah berasal dari bahasa Arab dengan akar kata jarama, yang berarti kesalahan, perbuatan dosa, kejahatan. Disebut jarama waajrama - wajtarama artinya berbuat dosa atau kesalahan, sama dengan aznaba. Al-Jarimah,

M Harvey Brenner, Pengaruh Ekonomi terbadap Perilaku Kejahatan, Jakarta, Rajawali, 1986, hlm. 3. jamaknya jaraaim adalah al-zanbu wa al-khatha'u, artinya dosa, kesalahan atau kejahatan, yang perbuatan itu diancam dengan hukuman. Kata ini sama maknanya dengan delik. Dikatakan jarimah al-sariqah, artinya delik pencurian. ${ }^{6}$

Menurut al-Raghib al-Isfahani, asal makna kata jarama adalah qath'us-samarati 'anis-sajari, artinya memetik buah dari pohon. Kata ini dalam berbagai bentuknya terdapat di dalam Alquran sebanyak 66 tempat. Dalam bentuk fi'il madhi 9 tempat, fi'il mudhari' 4 tempat, isim mashdar 1 tempat dan isim fa'il 52 tempat. Dengan demikian kata ini paling banyak muncul dalam bentuk isim fa'il yaitu mujrim, orang yang melakukan jurm atau jarimah. ${ }^{7}$

Padanan kata yang identik dengan jarimah dalam bahasa Indonesia adalah delik. Delik artinya perbuatan yang dapat dikenai hukuman karena melanggar atau bertentangan dengan undang-undang, atau disebut juga tindak pidana. ${ }^{8}$ Padanan kata lainnya adalah perbuatan pidana, perkara pidana, seperti kejahatan tentang pembunuhan, perampokan, korupsi dan berbagai bentuk kriminal lainnya. ${ }^{9}$ Istilah delik tersebut dalam bahasa Inggris, disebut delinquency, artinya kejahatan, pelanggaran dan kenakalan. Kata ini identik pula dengan crime, criminal, suatu perbuatan yang bersifat kejahatan. ${ }^{10}$ Kriminal, kriminalitas merupakan perbuatan kejahatan, seperti pembunuhan, perampokan, penipuan dan sebagainya. ${ }^{11}$

Dari keterangan di atas dapat dipahami bahwa jarimah berarti perbuatan jahat dan melanggar hukum yang dapat dijatuhi suatu hukuman. Jarimah di sini identik dengan delik, kriminal dan atau tindak pidana. Selain itu masih ada istilah lagi yang biasa dipakai oleh para ahli hukum Islam untuk menyebut perbuatan jahat, yaitu jinayah. Ahmad Hanafi menerangkan, para fuqaha sering memakai kata-kata jinayah untuk menyebut jarimah. Semula pengertian jinayah ialah hasil

6 Ahmad Warson Munawwir, Kamus al-Munawwir, Yogyakarta, Pustaka Progressif, 1984, hlm. 201.

7 al-Ragib al-Isfahani, Mufradat Alfazh al-Quran, Beirut, Dar al-fikr, tth, hlm. 89.

8 Departemen P\&K RI, Kamus Besar Bahasa Indonesia, Jakarta, Balai Pustaka, 1990, hlm. 641.

9 Ibid.

10 Abdul Sani, Sosiologi Kriminalitas, Bandung, Remaja Rosdakarya, 1987, hlm. 11.

11 Soedjono D., Penanggulangan Kejahatan, Bandung., Alumni, 1987, hlm. 30. 
perbuatan seseorang, yang biasanya dibatasi kepada perbuatan yang dilarang saja.

Di kalangan fuqaha, yang dimaksud dengan jinayah ialah perbuatan yang dilarang oleh syariat, baik perbuatan itu mengenai (merugikan) jiwa, maupun harta benda atau lainnya. Akan tetapi kebanyakan fuqaha memakai kata-kata jinayah hanya untuk perbuatan yang mengenai jiwa atau anggota badan, seperti pembunuhan, melukai, memukul, menggugurkan kandungan dan sebagainya. Ada pula golongan fuqaha yang membatasi pemakaian istilah jarimah terbatas kepada jarimah budud dan qisas saja. Dengan mengesampingkan perbedaan. pemakaian istilah jinayah di kalangan fuqaha, dapatlah dikatakan bahwa jinayah dengan jarimah pada dasarnya sama saja. $^{12}$

Dengan demikian walaupun terdapat perbedaan peristilahan, namun pengertiannya sama saja. Dalam tulisan ini penulis akan menggunakan istilah jarimah ketika terkait dengan hukum Islam, dan kadang-kadang juga digunakan istilah delik ketika terkait dengan hukum Positif. Yang jelas jarimah atau delik itu adalah suatu perbuatan melanggar hukum, yang ancamannya sudah diatur dalam hukum Islam atau hukum positif.

Suatu perbuatan dapat dikatakan sebagai jarimah atau delik apabila memenuhi beberapa persyaratan, yaitu :

1. Harus ada suatu perbuatan manusia;

2. Perbuatan itu harus sesuai dengan apa yang dilukiskan di dalam ketentuan umum;

3. Harus terbukti adanya dosa pada orangorang yang berbuat yaitu orangnya harus dapat dipertanggung jawabkan;

4. Perbuatan itu harus berlawanan dengan hukum;

5. Terhadap perbuatan itu harus tersedia ancaman hukumannya di dalam UndangUndang. ${ }^{13}$

Jadi diberlakukannya suatu hukuman atas suatu jarimah atau delik adalah jika syarat-syarat penunjangnya sudah lengkap dan terpenuhi. Dalam arti ada perbuatan manusia (bukan binatang) yang melanggar hukum sesuai aturan yang berlaku, manusia itu mampu bertanggung

12 Ahmad Hanafi, Asas-asas Hukum Pidana Islam, Jakarta, Bulan Bintang, 1970, hlm. 1-2.

13 R. Tresna, Asas-asas Hukum Pidana, Jakarta, Bina Aksara, 1990, hlm. 28. jawab atas dirinya (bukan anak kecil, gila atau terpaksa). Kemudian ada ancaman sanksi hukum yang mengatur pada setiap jarimah atau delik. Aturan hukum berikut sanksinya itu harus bersifat tertulis dan sudah ada sebelum perbuatan itu dilakukan.

Dari penjelasan di atas dapat dipahami. Pertama, setiap perbuatan baru dianggap sebagai jarimah atau delik apabila sudah jelas ada aturan hukumnya secara tertulis, bukan hukum lisan berupa Hukum Adat atau tradisi suatu masyarakat yang biasanya tidak tertulis. Kedua, aturan hukum tertulis itu harus mendahului suatu perbuatan jarimah. Misalnya seseorang melakukan jarimah perkosaan, maka untuk bisa dihukum, aturan hukum tentang perkosaan dan ancaman hukumannya harus lebih dahulu ada. Sekiranya belum ada, lalu dibuat kemudian, maka hukum tidak bisa menjerat perbuatan jarimah sebelumnya, karena hukum demikian tidak berlaku surut.

Itulah sebabnya pada setiap produk hukum atau perundang-undangan, terutama dalam Hukum Positif, selalu ada ketentuan bahwa Undang-Undang tersebut mulai berlaku sejak diundangkan. Berbeda dengan Hukum Islam, karena sudah ada aturan hukumnya yang termuat dalam sumber hukum Alquran, hadis dan pendapat para ulama, maka otomatis berbagai jarimah dapat dikenai hukuman bila memang suatu perbuatan tersebut benar-benar bersifat jarimah.

Inti dari aturan hukum jarimah atau delik adalah untuk mewujudkan keamanan, kedamaian dan ketertiban di tengah masyarakat. Sebab suatu kejahatan apa pun bentuknya akan merusak keamanan dan kedamaian tersebut. Menurut Paul Madigdo Moliono, kejahatan adalah perbuatan manusia yang merupakan pelanggaran normanorma yang merugikan, menjengkelkan, menimbulkan korban, sehingga tidak dapat dibiarkan. Tidak dapat dibiarkan berarti masyarakat tidak menghendaki adanya perbuatan tersebut. ${ }^{14}$

Adanya ketentuan hukum tentang jarimah, adalah juga untuk menegakkan nilai-nilai luhur yang ada pada masyarakat. Hal ini dalam Islam merupakan bagian dari syariat. Sayyid Sabiq menyatakan, "semua ajaran dan ketentuan hukum yang ada pada syariat Islam adalah untuk

14 Ninik Widyanti, Kejahatan dalam Masyarakat dan Pencegahannya, Jakarta, Bumi Aksara, 1987, hlm. 29. 
menjaga agama (bifzh al-din), menjaga jiwa (bif₹̧ al-nafs), menjaga akal (bifæ̧ al-aq), menjaga keturunan (bif 2 h al-nas), dan menjaga harta (bif $\not$ h al-mal)". 15

Apabila suatu jarimah tidak dilarang dan dikenakan hukuman, maka nilai-nilai luhur dalam hidup ini tidak akan terjaga. Apabila penistaan agama dibiarkan, berarti agama tidak akan terjaga. Apabila pembunuhan dan penganiayaan tidak dilarang dan dihukum, berarti jiwa (nyawa) tidak terjaga. Apabila peredaran minuman keras dan narkoba tidak dilarang, berarti akal tidak terjaga, sebab keduanya sangat merusak akal pikiran. Apabila perzinaan dan pelacuran tidak dilarang, berarti akan merusak keturunan. Apabila pencurian, perampokan, penipuan, korupsi dan sejenisnya tidak dilarang dan dikenakan hukuman, berarti tidak menjaga harta, baik harta perorangan, kelompok maupun harta negara.

Perbuatan jarimah sangat banyak jenis atau macamnya, sebanyak perbuatan melanggar hukum yang dilakukan oleh manusia. Tetapi oleh para ulama, jarimah tersebut dibagi-bagi dalam golongan-golongan khusus dengan melihat kepada sifat atau jenis jarimah itu sendiri. Dalam hal ini meliputi :

a. Dilihat dari segi berat ringannya hukuman, jarimah dibagi tiga, yaitu jarimah budud, jarimah qisas-diyat dan jarimah ta'zir,

b. Dilihat dari segi niat si pelaku, jarimah dibagi dua, yaitu jarimah sengaja dan jarimah tidak sengaja;

c. Dilihat dari segi cara melakukannya terbagi dua, yaitu jarimah positif dan jarimah negatif;

d. Dilihat dari segi orang yang menjadi korban akibat perbuatan, jarimah terbagi dua, yaitu jarimah perorangan dan jarimah masyarakat;

e. Dilihat dari segi sifat atau tabiatnya, jarimah terbagi dua, yaitu jarimah biasa dan jarimah politik. ${ }^{16}$

\section{Tinjauan Kasus}

Jika ditinjau dari sudur pandang hukum pidana Islam, maka dari ke-9 kasus eksekusi mati di atas, ada yang sesuai dan ada yang tidak sejalan dengan hukum Islam. Berkaitan dengan 9 kasus eksekusi mati sebagaimana disebutkan di atas, di sini dibahas sebagai berikut:

\footnotetext{
15 Al-Syaikh Sayyid Sabiq, Fiqh al-Sunnah, Jilid I, Beirut, Dar al-Fikr, 1403 H, hlm. 10.

16 Ahmad Hanafi, Op.cit., h. 6-7.
}

\section{Kelompok pertama}

Kelompk pertama terdiri dari Kusni Kasdut. Jika dilihat dari hukum pidana Islam, apa yang dilakukan oleh Kusni Kasdut termasuk kejahatan jarimah birabah, yaitu perampokan (pencurian yang disertai dengan kekerasan dan pembunuhan). Jarimah pencurian terbagi dua, yaitu pencurian kecil (al-sariqah al-shugra), yaitu mengambil harta yang bukan haknya secara sembunyi-sembunyi, dan pencurian besar (alsariqah al-kubra), yaitu mencuri harta yang bukan haknya dengan cara merampas atau terangterangan, yang biasa disebut perampokan (albirabab). ${ }^{17}$

Dalam hukum pidana Islam ada beberapa jarimah yang kepada pelakunya dapat dikenakan hukuman mati, salah satu di antaranya yaitu jarimah hirabah. Kejahatan ini dapat dikenai hukuman berat, yaitu dengan cara dibunuh dan disalib, dipotong tangan dan kakinya secara menyilang atau dibuang ke tempat yang jauh dari negerinya. Kecuali bagi pelaku hirabah (mubarib) yang insaf (bertaubat) sebelum tertangkap, maka mereka ini diampuni (QS al-Maidah ayat 33-34).

Untuk dapat dikenai hukuman mati, maka pelaku jarimah hirabah harus memenuhi empat persyaratan. Pertama, pelakunya orang yang mukallaf (dewasa, berakal). Kedua, pelaku membawa atau menggunakan senjata yang berbahaya, baik senjata tajam, senjata api dan sejenisnya. Ketiga, lokasi hirabah jauh dari keramaian, semacam samun atau gerombolan, sebab kalau di keramaian korban akan dapat ditolong oleh polisi. Keempat dilakukan secara terang-terangan. Kalau dilakukan secara sembunyi-sembunyi, maka hukumannya kembali ke hadd pencurian, dengan sanksi potong tangan jika memenuhi nisab. ${ }^{18}$

Dengan demikian, hukuman mati yang dikenakan kepada Kusni Kasdut dapat dipandang sah menurut hukum Islam, sebab ia merampok dan juga membunuh korbannya. Walaupun ia non muslim, tetapi jika tinggal di negara yang memberlakukan hukum Islam, maka hukuman mati dapat dikenakan atas kejahatannya, sebab hukum pidana Islam juga berlaku atas non muslim. Non muslim hanya berhak menggunakan hukum sendiri terkait dengan ibadahnya, perkawinan dan sejenisnya.

\footnotetext{
17 Abdulqadir Audah, al-Tasyri al-jina'i al-Islami, Juz II, Beirut, Dar al-Fikr, tth, hlm. 514.

$18 \quad$ Ibid., h. 177.
} 


\section{Kelompok kedua}

Pelaku tindak pidana yang dapat digolongkan ke dalam kelompok kedua ini terdiri dari Rio Alex, Oesin Baftari, Sumiasih cs dan juga Ayub Bulubili. Mereka membunuh secara berencana karena latar belakang ekonomi, mungkin utang piutang, penipuan, penggelapan dan sebagainya.

Dalam pandangan hukum pidana Islam, kejahatan yang dilakukan oleh para pelaku di atas tergolong ke dalam jarimah qisas-diyat. Jarimah qisas-diyat maksudnya adalah perbuatan jarimah yang dapat dikenakan hukuman qisas atau diyat, yang telah ditentukan batasannya, dan tidak mempunyai batas terendah atau tertinggi, tetapi menjadi hak perorangan. Jika korban atau keluarganya memaafkan pelaku, maka hukuman qisas bisa berubah jadi diyat atau hapus sama sekali karena dimaafkan. ${ }^{19}$

Jarimah qisas-diyat terbagi lima, yaitu:
a) pembunuhan yang disengaja (al-qatlu al- amdu);
b) pembunuhan semi sengaja (al-qatlu syibhu al-amdu);
c) pembunuhan karena kekhilafan (tidak sengaja) atau disebut (al-qatlu al-khata);
d) penganiayaan sengaja (al-jarbu al-amdu);
e) penganiayaan tidak sengaja (al-jarbu al- khata). ${ }^{20}$

Pembunuhan sengaja misalnya menembak seseorang yang tidak bersalah dengan senjata api. Pembunuhan ini direncanakan lebih dahulu. Dalam praktiknya, kelihatannya para pelaku memang merencanakan kejahatannya, misalnya dengan menyiapkan senjata, merencanakan waktu dan tempat serta cara menghilangkan jejak.

Pembunuhan semi sengaja misalnya sengaja menempeleng orang untuk menyakiti, tetapi ternyata korbannya mati. Pembunuhan karena khilaf misalnya menembak hewan buruan, ternyata terkena manusia dan mati. Penganiayaan sengaja misalnya sengaja memukul orang sehingga luka atau patah tulang. Penganiayaan tidak sengaja seperti menembak burung dengan ketapel dan terkena manusia, sehingga menimbulkan luka atau sakit luar biasa.

Dalam jarimah qisas-diyat ini, hukumannya sama dengan yang dilakukan pelaku. Jika membunuh, hukumannya qisas dengan dibunuh pula, bila melukai dilukai pula, kecuali kalau ada

19 Ahmad Hanafi, Op.cit., h. 7-8.

20 Ibid., h. 8. pemaafan maka dapat diganti dengan diyat, demikian seterusnya. Untuk pembunuhan karena khilaf atau penganiayaan tidak sengaja dapat diselesaikan secara kekeluargaan dengan jalan damai, dengan atau tanpa diyat.

\section{Kelompok ketiga}

Untuk kasus Salman Hafiz, Imran dan Amrozi cs dapat didekati dengan menggunakan jarimah politik, yaitu bughat (makar atau pemberontakan terhadap negara). Ini biasa disebut dengan jarimah politik, kejahatan terhadap pemerintah atau negara atau penguasa yang sah. Kejahatannya dengan cara membunuh pimpinan negara, pejabat negara atau aparat negara, atau siapa pun dengan motif politik.

Diriwayatkan bahwa pada malam 17 Ramadhan tahun $40 \mathrm{H}$ (661 M), Khalifah Ali dibunuh oleh Abdurrahman bin Muljam alMuradi, seorang tokoh golongan Khawarij. Menjelang wafat, Ali berpesan kepada pengikutnya: Jangan kalian perangi kaum Khawarij sepeninggalku, sebab mereka itu mencari kebenaran namun jatuh keliru. Berbeda dengan pihak yang menonjolkan kepalsuan lalu mempertahankannya (golongan Muwaiyah). ${ }^{21}$ Riwayat lain menjelang wafat, Ali berpesan, ketahuilah, jangan sampai kamu bunuh karena aku, kecuali pembunuh diriku. Jika aku tewas karena pukulannya, maka pukullah seperti ia memukulku, dan jangan kamu cencang. ${ }^{22}$

Versi lain mengatakan, menjelang wafat Ali berkata kepada putranya al-Hassan. Tawanlah dia baik-baik. Kalau saya hidup, maka sayalah yang berkuasa atas jiwanya, dan kalau aku mati, maka bunuhlah dia seperti dia membunuhku. Katakata Ali ini oleh para ulama dianggap bahwa walau Ali terbunuh dalam kondisi politik yang tidak stabil, namun Ali ingin menganggap pembunuhan atas dirinya sebagai pembunuhan biasa saja, di mana berlaku qisas.23

Karena itu jarimah politik baru bisa dikenakan apabila situasinya benar-benar khusus dan luar biasa, sehingga dapat disebut jarimah politik, yang istilah khususnya adalah al-baghyu

21 Joesoef Sou'yb, Sejarah Daulat Khulafaur Rasyidin, Jakarta, Bulan Bintang, 1979, hlm. 531.

22 Muhammad Abduh, Nabjul Balaghah, Alih bahasa Yunus Ali al-Muhdar, Imam Ali bin Abi Thalib dalam Nabjul Balaghah, Surabaya, Pelita Ilmu, 1991, hlm. 130.

23 Ahmad Hanafi, Op.cit., hlm. 18. 
(pemberontakan), dan pelakunya disebut albughaat atau al-fiat al-baghiyah .

Dimaksudkan dengan al-bugbaat di sini adalah orang-orang yang memberontak kepada imam (penguasa negara) berdasarkan takwil atau alasan tertentu dan mempunyai kekuatan tertentu. Mereka melawan penguasa tertingi (al-imam ala'rham), karena dua hal: Pertama, tidak mau melaksanakan suatu kewajiban misalnya zakat, atau hukum syara' lainnya yang berhubungan dengan hak Allah dan hak manusia, atau tidak mau menyatakan bai'at (setia) kepada pemimpin yang terpilih. Kedua, hendak mencopot penguasa tertinggi karena dipandang menyeleweng. Penguasa yang dilawan dan ingin digulingkan tersebut disebut ablu al-'adli.24

Indikator suatu golongan dapat disebut melakukan jarimah politik berupa al-baghyu meliputi:

a) Tidak taat kepada pemerintah yang sah dan adil, yang oleh Allah diwajibkan atas kaum muslimin sebagai wali al-amr.

b) Orang-orang yang tidak mau taat itu adalah golongan yang kuat dan memiliki senjata, sehingga untuk mengembalikannya kepada ketaatan, pemerintah memerlukan banyak manusia (tentara), persiapan materi dan persenjataan untuk memeranginya.

c) Mereka mempunyai alasan yang kuat untuk tidak taat tersebut. Jika tidak punya alasan yang kuat, mereka bukan bughaat, melainkan mubaribin (pengacau keamanan) seperti diuraikan sebelumnya.

d) Mereka mempunyai pimpinan yang ditaati sebagai sumber kekuatan, sebab tidak ada kekuatan kelompok tanpa pemimpin. ${ }^{25}$

Versi lain menyatakan indikator dimaksud meliputi:

a) Adanya tujuan, yaitu ingin menggulingkan pemerintah yang sah dan tidak mau tunduk kepadanya;

b) Adanya alasan (takwil) yang menurut pandangan mereka benar, sekalipun salah dan lemah. Misalnya golongan Muawiyah yang memberontak terhadap Ali bin Abi Thalib beralasan, Ali sebenarnya mengetahui pelaku pembunuhan Usman bin Affan, tetapi tidak bertindak bahkan bersekongkol dengan mereka sebelumnya.

24 Ibid., hlm. 19-20.

25 Al-Syaikh Sayyid Sabiq, Op.cit., Jilid III, hlm. 12. c) Adanya suasana pemberontakan dan perang saudara yang dikobarkan untuk mewujudkan maksud-maksud jarimah politik ini. Kalau tidak dilakukan dalam suasana perang atau pemberontakan, maka ia digolongkan sebagai jarimah biasa. ${ }^{26}$

Hukuman yang dijatuhkan atas pelaku jarimah politik setimpal dengan perbuatannya. Kalau mereka menculik, menawan dan membunuh orang- orang pemerintahan, menguasai harta negara, merusak jalan, jembatan dan fasilitas umum, membakar gedung dan gedung pangan atau mesiu, maka mereka boleh diperangi, dibunuh dan dirampas harta kekayaannya sekadar untuk menumpas gerakan mereka. Kalau negara sudah mampu menguasai, dan pemberontak sudah menyerah, meletakkan senjatanya, maka jiwa dan harta mereka tidak boleh diganggu lagi. Penguasa bisa mengampuni mereka (memberi amnesti), atau menjatuhkan hukuman ta'zir atas penyelewengan mereka, bukan karena jarimah politiknya. Hukuman ta'zir yang dijatuhkan bersifat memberi pelajaran agar mereka menyadari kesalahannya. ${ }^{27}$

Jadi dalam jarimah politik yang terjadi dalam suasana peperangan tersebut, hukumannya adalah diperangi dan saat peperangan itu dibolehkan membunuh dan merampas hartanya. Tetapi ketika pemerintah yang sah sudah menguasai keadaan, maka pelaku jarimah politik tidak perlu dikejar dan dicari ke tempat persembunyiannya. Bagi yang tertangkap, bisa diberi amnesti dan bisa pula dikenakan hukuman ta'sir.

Kebolehan menjatuhkan hukuman mati di atas, berlaku di negara Islam. Berkaitan dengan Indonesia, tentu menjadi masalah pelik. Mereka yang melakukan jarimah itu tidak mau taat kepada pemerintah Indonesia, karena negara ini dianggap tidak berdasarkan hukum Islam, tidak menjalankan syariat Islam, atau tegasnya bukan negara Islam. Sementara kewajiban taat kepada pemerintah (Ulil Amr) itu berlaku jika negara menjalankan hukum Islam (QS An Nisa ayat 59).

Tetapi di dalam hadis anjuran taat ini berlaku, sepanjang isi perintah itu sejalan dengan ajaran agama, atau tidak bertentangan dengan ajaran agama, atau tidak disuruh taat untuk melakukan maksiat. Mengingat aturan pemerintah selama ini pada dasarnya masih sejalan, atau tidak

26 Ahmad Hanafi, Op.cit., hlm. 20-21.

27 Ibid., hlm. 21-22. 
bertentangan dengan syariat, maka pada dasarnya kewajiban taat masih berlaku. Berarti mereka yang melawan pemerintah dengan menggunakan kekerasan senjata dapat dianggap sebagai tindakan bughat, atau makar, melawan pemerintah yang sah. Meskipun kekuatan mereka tidak terlalu besar, tetap saja membahayakan, terbukti sejumlah aksi pemboman dan penembakan polisi yang mereka lakukan, tidak saja membahayakan masyarakat umum yang tidak berdosa, tettapi juga aparat kepolisian.

Seharusnya mereka memperjuangkan aspirasinya secara bijaksana dan sesuai aturan, misalnya melalui gerakan amar ma'ruf nabi munkar, melalui perubahan konstitusi di DPR, melalui demonstrasi yang tidak anarkis dan sebagainya. Bukan melalui aksi pemboman yang mebahayakan diri sendiri dan orang lain. Jadi kepada mereka memang bisa saja dikenakan hukuman mati. Meskipun demikian, masalah ini tetap menimbulkan kontroversi.

\section{Kelompok keempat}

Kelompok keempat terdiri dari Chaubey cs, yang melakukan kejahatan penyelundupan atau peredaran narkotika. Jika dilihat dari hukum Islam, maka hukuman mati yang dijatuhkan kepada mereka tidak begitu sejalan dengan hukum Islam. Sebab kejahatan narkotika dalam hukum Islam digolongkan ke dalam minuman keras (khamr) yang terkena hukuman hadd saja.

Khamr adalah minuman keras, bahan yang mengandung alkohol yang bila diminum atau dikonsumsi akan memabukkan. ${ }^{28}$ Selain berupa minuman, bahan-bahan yang dapat menghilangkan akal, seperti ganja (basyisy), narkotika dan berbagai jenisnya juga diharamkan. Rumus pengharaman ini mengacu kepada hadis riwayat Imam Suyuthi, bahwa setiap sesuatu yang memabukkan disebut khamr, dan setiap khamr hukumnya haram, baik sedikit maupun banyak, baik konsumennya sampai mabuk atau tidak. ${ }^{29}$

Orang yang meminum khamr dikenakan deraan (pukulan). Kalangan mazhab Hanafi dan Maliki mengacu kepada riwayat Rasulullah dan

28 Yusuf al-Qardhawi, Halal dan Haram dalam Islam, Alih bahasa Mu'ammal Hamidy, Surabaya, Bina Ilmu, 1980, hlm. 91.

29 Al Imam Jalaluddin Abdirrahman bin Abibakar alSuyuthi, al-Jamiush Shagir, Juz 2, Surabaya, Dar alIhya, tth, hlm. 94.
Abu Bakar menghukum peminum khamar 40 kali dan Umar menghukum 80 kali. ${ }^{30}$

Di dalam Alquran, larangan meminum khamr ditegaskan dalam QS al-Baqarah ayat 219, anNisa ayat 43 dan al-Maidah ayat 90-91. Pelarangan minuman keras mulanya bertahap, tetapi kemudian keharamannya dipertegas, dengan disertai hukuman.

Pelaku yang terkena hukuman tidak saja peminum, tetapi juga produsen (pembuatnya), distributor (pengedarnya), pembawanya, pengirim, penuang, penjual, pembayar, pemesan dan pemakan hasilnya.

Tetapi kejahatan ini dapat juga ditarik menjadi hukuman ta'zir. Jika pemerintah, dalam hal ini menganggap pelaku sangat berbahaya, misalnya selalu mengulang kejahatannya, dan kejahatannya membahayakan orang banyak, maka dapat dikenakan hukuman ta' $2 i$ r. Dalam hal hukuman ta'₹ir, hukuman maksimalnya menurut sebagian ulama Hanafiyah boleh sampai kepada hukuman mati. Sebagaimana pemerintah boleh melebihkan hukuman hadd atas pelaku jarimah, sekiranya pemerintah (hakim) menganggapnya perlu. Namun menurut sebagian ulama lain, untuk jarimah yang sudah ada ketentuan haddnya maka tidak boleh menjatuhkan melebihi ketentuan yang sudah ada. ${ }^{31}$

Dalam hal kejahatan penyalahgunaan narkotika, memang ditandai semakin maraknya peredarannya di tengah masyarakat, sehingga mengakibatkan semakin banyaknya terjadi kerugian material atau finansial. Sebuah majalah ibukota (2009) menyatakan bahwa berdasarkan hasil penelitian yang dilakukan oleh Badan Narkoba Nasional (BNN) dan Pusat Penelitian Kesehatan Universitas Indonesia di 10 kota, diketahui pencandu narkoba di tanah air mencapai 3,2 juta orang. Dari jumlah ini maka dikalkulasi kerugian material akibat narkoba adalah Rp 23,6 triliun per tahun, dan jumlah ini akan terus meningkat. ${ }^{32}$

Penyalahgunaan narkoba adalah salah satu kejahatan yang sangat berbahaya dan merugikan banyak pihak, tidak saja pelaku tetapi juga orang lain. ${ }^{33}$ Kejahatan ini merambah ke mana-mana, termasuk Kalimantan Selatan. Wakil Gubernur

\footnotetext{
Sayyid Sabiq, Op.cit., hlm. 77-78.

Ibid, juz 10, hlm. 155.

32 Tim Redaksi, "Negeri Junkies, Majalah "Sabili", No. 18, Tahun XVI, 26 Maret 2009, hl 7.

33 Sofyan S. Willis. 1990. Problema Remaja dan Pemecahannya. Bandung:, Angkasa, 1980, hlm.60.
} 
Kalimantan Selatan, Rudy Resnawan mengungkapkan bahwa pengguna narkoba di Kalsel mencapai angka 120.131 orang $^{34}$

Jadi mengigat bahayanya yang besar dan sangat merugikan, bisa saja pelaku (produsen, pengedar, penjual) dan sebagainya dikenakan hukuman maksimal, termasuk hukuman mati.

\section{Celah Pengampunan}

Berkaitan dengan tindak pidana pembunuhan sengaja, sebagaimana dilakukan oleh para terpidana mati (kelompok kedua), sebenarnya ada celah pengampunan, khususnya bagi Sumiasih dan Sugeng yang membunuh Poerwanto sekeluarga. Hal ini karena setelah melalui masa penahanan yang lama, menyebabkan pihak keluarga korban tidak terlalu menuntut hukuman mati itu harus dilaksanakan.

Sebagaimana diketahui Sumiasih dan Sugeng sebelum dieksekusi telah menjalani masa hukumannya di penjara selama 20 tahun, suatu masa yang cukup lama. Apabila upaya-upaya hukum tetap dibuka, sebaiknya rentang waktu tersebut digunakan para pihak berdamai atau mendapatkan pemaafan. Hukuman mati bisa dicegah jika pengadilan mengadopsi sebagian kecil saja dari hukum pidana Islam (HPI). Pembunuhan dalam HPI dikenakan sanksi qishasdiyat.

Dalam kasus Sumiasih, keluarga Poerwanto yang diwakili Haryo Abrianto, anak Poerwanto yang selamat, sudah memaafkan. Selebihnya hanya urusan Sumiasih cs dengan Tuhan saja, ujarnya. ${ }^{35}$ Dilihat dari HPI, pemaafan tersebut membuka peluang beralihnya hukuman dari mati (qisash) menjadi kompensasi (diyat). Sanksi pelaku pembunuhan bukan wewenang negara, melainkan hak keluarga korban, sebab keluargalah yang paling dekat dan menderita. Tuhan akan memaafkan jika keluarga memaafkan. Jika keluarga korban tidak memaafkan, pelaku harus dieksekusi mati. Sebaliknya jika keluarga memaafkan, bisa diganti dengan kompensasi yang disepakati. Negara melalui instrumen peradilan dapat melakukan upaya hukum mendekati keluarga korban agar pelaku dimaafkan.

\footnotetext{
34 "120 ribu Warga Kalsel Jadi Budak Narkoba", www.detiknews.net, diakses tanggal 22 Maret 2012.

35 "Keluarga Poerwanto Memaafkan Sumiasih". Jawa Pos 20 Juli 2008.
}

Jadi sebenarnya, Sumiasih dan Sugeng dapat dimaafkan setelah menjalani masa hukumannya selama 20 tahun tersebut. Pembebasannya dapat dilakukan dengan diyat atau tanpa diyat, karena pihak keluarga sudah memaafkan.

Pemaafan yang berujung pada dibebaskannya terpidana mati demikian banyak diberlakukan di Negara Islam semisal Arab Saudi. Di satu sisi Arab Saudi memang sering melaksanakan hukum mati. Setahu saya, di kota Jeddah pinggiran laut Merah, ada yang namanya Masjid Qisas Di situ sering dilakukan pemancungan terhadap terpidana mati, yang darahnya dialirkan ke laut.. Begitu juga di kota Mekkah dan Madinah disediakan tempat pelaksanakan qisas. Hal ini karena Negara ini menerapkan hukum Islam secara ketat.

Namun di sisi lain, celah pengampunan juga tetap terbuka. Hukum Islam memandang bahwa pembunuhan menyangkut hak 'adami (hak manusia), yaitu keluarga korban, sebab keluarga korbanlah yang paling menderita dengan hilangnya nyawa keluarganya. Jika keluarga tidak memaafkan, seperti kasus Ruyati, maka eksekusi mati menjadi sanksinya.

Sebaliknya, jika keluarga memaafkan, maka pembunuhan sebagai tindak pidana bisa berubah menjadi perdata. Sanksinya bukan lagi nyawa, melainkan diyat (ganti rugi, kompensasi). Pelaku, keluarga atau pemerintah bisa memberi keluarga korban dengan harta atau uang dalam jumlah tertentu. Hal beginilah yang dialami oleh Darsem, TKW asal Jawa Barat di mana keluarga korban yang dibunuhnya bersedia berdamai dengan diyat. Bahkan, tidak mustahil keluarga korban juga bersedia memaafkan tanpa harus ada diyat. Pemaafan (al-qawdu) demikian sungguh terpuji dalam Islam dan sangat dekat kepada taqwa. Beberapa TKW Indonesia yang dijatuhi vonis mati, juga ada yang berhasil dibebaskan karena pihak keluarga korban kemudian memaafkan.

Islam mengajarkan, sekiranya keluarga rela, memaafkan pelaku justru lebih baik dan hal itu lebih dekat kepada taqwa. Pada beberapa kasus, ada juga keluarga korban yang memaafkan, dan tanpa diyat, sehingga pelaku bebas. Tetapi Islam tetap memgembalikan semuanya pada keluarga.

Alternatif hukum diyat sebagai pengganti qisas inilah yang bisa menjadi celah lepasnya terpidana mati dari eksekusi. Negara lain juga sering mengusahakan cara demikian. Salah satu contohnya adalah Sarah Balabagan, TKW asal Cotabatu Mindanao Filipina. Ia termasuk orang 
beruntung lepas dari hukuman mati, karena keluarga korban yang dibunuhnya di Arab Saudi bersedia memaafkannya. Hal ini setelah pemerintah Filipina gigih mencarikan upaya hukum menyelamatkan Sarah dan bersedia membayarkan diyatnya. Semula keluarga korban tidak bersedia memaafkan, tetapi lama kelamaan ia dimaafkan, sehingga Sarah akhirnya bebas.

Upaya hukum demikian mestinya dapat diberikan kepada Sumiasih dan Sugeng, karena keluarga korban sudah memaafkan. Tetapi karena Indonesia tidak menganut hukum Islam, akhirnya Sumiasih dan Sugeng tetap dieksekusi, padahal sudah 20 tahun menjalani hukuman penjara. Ini berarti hukuman yang diterima keduanya menjadi berganda, yajtu hukuman penjara 20 tahun dan hukuman mati. Penantian panjang menunggu grasi menjadi sia-sia. Indonesia kelihatannya tidak memberlakukan kepastian dan kecepatan dalam proses hukum. Misalnya terpidana mati kasus subversif G $30 \mathrm{~S}$ PKI, kejadiannya 1965, namun ada yang baru dieksekusi akhir 1980-an.

Di antara prinsip penjatuhan hukuman adalah cepat, sederhana dan berbiaya ringan. Dalam Undang-Undang Nomor 48 tahun 2009 tentang Kekuasaan Kehakiman, pasal 2 ayat 4 menyatakan bahwa peradilan dilakukan dengan sederhana, cepat dan biaya ringan. Cepat, maksudnya peradilan sebagai institusi sistem peradilan dapat menjamin tercapainya atau terwujudnya keadilan dalam penegakan hukum oleh pencari keadilan secara cepat. Baik cepat dalam proses, cepat dalam hasil dan cepat terhadap evaluasi kinerja dan tingkat produktivitas institusi peradilan, dalam hal ini kepolisian, kejaksaan, pengadilan, lembaga pemasyarakatan dan advokat.

Waktu 20 tahun tersebut tentu amat lama untuk sebuah kepastian hukum. Kalau menurut hukum Islam, waktu sebelum esksekusi tersebut seharusnya digunakan untuk membujuk keluarga untuk memaafkan, dan nyatanya untuk kasus Sumiasih memang dimaafkan. Tetapi hukum Positif Indonesia tidak menganut cara demikian. Yang dilakukan justru memohonkan grasi kepada Presiden, yang tampaknya berliku-liku dan memakan waktu lama, dan setelah presiden menolaknya, akhirnya eksekusi pun dilakukan. Seharusnya, sebagaimana hukum Islam mengatur, grasi (pengampunan atau pemaafan) itu ada pada keluarga, bukan pemerintah. Kalau memohon maaf kepada keluarga masih ada harapan dimaafkan, karena setelah berlalu waktu yang lama mungkin keluarga korban tidak menaruh dendam lagi kepada pelaku dan berusaha melupakan kesedihan.

\section{Penutup}

Berdasarkan uraian di atas, jelas bahwa hukuman mati cukup banyak dilaksanakan di Indonesia, beberapa di antaranya sudah dieksekusi. Melihat jenis kejahatannya, tampak kebanyakan terpidana mari adalah kasus pembunuhan, terorisme, perampokan dan ada juga penyalahgunaan narkotika berupa pengedar narkotika.

Meskipun hukuman mati tersebut memiliki payung hukum yang kuat, namun dalam pelaksanaannya harus cermat. Khususnya untuk kasus pembunuhan yang sudah dimaafkan oleh keluarga korban, pemerintah perlu mengubah hukuman mati menjadi hukuman penjara. Dalam beberapa hal pemerintah perlu mengadopsi sebagian dari aturan hukum Islam yang lebih adil dan rasional.

Mengadopsi hukum Islam, masa tahanan terpidana menunggu eksekusi mestinya digunakan untuk upaya hukum untuk minta pemaafan keluarga korban, bukan untuk memohon grasi. Kalau keluarga memaafkan, seharusnya pemerintah membebaskan terpidana dan mengantinya dengan hukuman lain seperti penjara dan diyat (denda) sebagai kompensasi.

Akhir-akhir ini juga muncul wacana agar terpidana kasus-kasus korupsi kelas kakap juga perlu dikenakan hukuman mati. Sebab kejahatan korupsi tergolong luar biasa, sangat membahayakan bangsa dan negara. Ketika orang korupsi ratusan juta, miliaran atau triliunan rupiah, betapa besar manfaatnya jika dibangun sarana pendidikan, kesehatan, dibelikan beras miskin, BLT, memberdayakan petani, nelayan atau menolong orang sakit. Besarnya utang luar negeri, terkurasnya kekayaan alam dan terpuruknya negeri, banyak disebabkan ulah koruptor.

Sosiolog Universitas Airlangga Surabaya Hotman Siahaan menekankan, hukuman mati untuk koruptor perlu dilakukan sekarang, sebab korupsi di Indonesia luar biasa, membudaya dan di mata dunia dicap negara terkorup. Pendekar hukum Adnan Buyung Nasution mengaku, kalau dulu ia anti hukuman mati, maka kini ia juga setuju hukuman mati untuk pelaku korupsi.

Tetapi pakar hukum pidana Romli Atmasasmita menolak hukuman mati untuk koruptor, juga terpidana lain. Menurutnya, tidak 
ada bukti hukuman mati mampu mengurangi korupsi. Di RRC yang banyak menghukum mati koruptor, korupsi masih terjadi. 36

Meskipun demikian, pemerintah tetap perlu menjatuhkan hukuman yang seberat-beratnya untuk berbagai pelaku tindak pidana. Dengan begitu diharapkan ada efek jera bagi pelaku dan calon pelaku, serta terwujudnya keadilan di tengah masyarakat. Selama hukuman relatif ringan, apalagi terjadi permainan uang untuk meringankan dan membebaskan pelaku dari hukuman, maka selama itu keadilan akan sulit diwujudkan.

\section{Daftar Pustaka}

"120 Ribu Warga Kalsel Jadi Budak Narkoba", www.detiknews.net, diakses tanggal 22 Maret 2012.

"Amnesti Internasional Protes Hukuman Mati", Tempo, edisi Juni 2008.

Abduh, Muhammad, Nabjul Balaghah, Alih bahasa Yunus Ali al-Muhdar, Imam Ali bin Abi Thalib dalam Nabjul Balaghah, Pelita Ilmu, Surabaya, 1991.

Abdul Sani, Sosiologi Kriminalitas, Remaja Rosdakarya, Bandung, 1987).

Ahmad Hanafi, Asas-asas Hukum Pidana Islam, Bulan Bintang, Jakarta, 1970.

al-Isfahani , al-Ragib, Mufradat Alfazh al-Quran, Dar al-fikr, Beirut, tth.

Al-Qardhawi, Syekh Yusuf Halal dan Haram dalam Islam, Alih bahasa Mu'ammal Hamidy, Bina Ilmu, Surabaya, 1980.

Al-Suyuthi, Al Imam Jalaluddin Abdirrahman bin Abibakar, al-Jamiush Shagir, Juz 2, Dar alIhya, Surabaya, tth.

Audah, Abdulqadir, al-Tasyri' al-Jina'i al-Islami, Juz II, Dar al-Fikr, Beirut, tth.
Brenner, M Harvey, Pengaruh Ekonimi terbadap Perilaku Kejahatan, Rajawali, Jakarta, 1986.

Daulay, Zainuddin (Editor), Konflik Sosial Bernuansa Agama di Indonesia, Departemen Agama, Jakarta, 2003..

Departemen P\&K RI, Kamus Besar Babasa Indonesia, Balai Pustaka, Jakarta, 1990.

http:/ / forum.viva.co.id/aneh-dan-lucu/4409075-eksekusi-mati-paling-heboh-diindonesia.html

Joesoef Soua'yb, Sejarah Daulat Khulafaur Rasyidin, Bulan Bintang, Jakarta, 1979.

"Keluarga Poerwanto Memaafkan Sumiasih". Jawa Pos 20 Juli 2008.

Lubis, Todung Mulya (Editor), Langit Masih Mendung, Sinar Harapan, Jakarta, 1980.

Munawwir, Ahmad Warson, , Kamus al-Munawnir, Pustaka Progressif, Yogyakarta, 1984.

Sabiq, Al-Syaikh Sayyid, Fiqh al-Sunnah, Jilid I, Dar al-Fikr, Beirut, $1403 \mathrm{H}$.

Soedjono D., Penanggulangan Kejahatan, Alumni, Bandung, 1987.

Tim Redaksi, "Negeri Junkies, Majalah "Sabili", No. 18, Tahun XVI, 26 Maret 2009.

Tresna, R., Asas-asas Hukum Pidana, Bina Aksara, Jakarta, 1990.

Undang-Undang Nomor 48 tahun 2009 tentang Kekuasaan Kehakiman

Widyanti, Ninik, Kejahatan dalam Masyarakat dan Pencegahannya, Bumi Aksara, Jakarta, 1987.

Willis, Sofyan S., Problema Remaja dan Pemecabannya. Angkasa, Bandung, 1980..

36 “Indonesia Malam TVOne”, 1 Oktober 2013. 